\title{
Enhancing Teaching and Learning in Ghana through Process Drama
}

\author{
Faustina Brew \\ Department of Theatre Arts, University of Education, P. O. Box 25, Winneba, Ghana \\ E-mail: faubw@yahoo.com
}

\begin{abstract}
Process drama, popularised by Heathcote and other practitioners, is acclaimed effective medium of teaching and learning in many countries. This learning procedure has not been significantly explored in Ghana. Working with non-drama teachers with my role as a facilitator, participant, and observer, we explored the use of dramatization and mantle of the expert procedures for the teaching and learning of various school subjects. This paper elaborates on engagements with teachers and pupils in the use of process drama to enhance teaching and learning as well as the challenges encountered by the teachers. In this sample study, it was observed that some participants made significant achievements in the use of process drama despite the challenges of space and large class sizes. It is however recommended that non-drama teachers are introduced to much simpler drama games and strategies which might work better in current classroom context.
\end{abstract}

Keywords: process drama; dramatization; mantle of the expert; pedagogy

DOI: $10.7176 / \mathrm{JEP} / 13-6-06$

Publication date: February $28^{\text {th }} 2022$

\section{Introduction}

It has been established by educational drama practitioners that the use of drama related activities in the teaching of school subjects result in greater achievements for learners. In Ghana however, drama is often used as a form of entertainment during school ceremonies such as speech and prize giving days. Occasionally, schools organize sponsored drama competitions, which are created on specific themes for mass education. The benefits of drama for participating children have not been adequately explored in the country. Apparently, the lack of significant research into educational drama and its benefits has invariably contributed to this predicament. It is against this background that this study engaged twelve primary school teachers to explore the benefits of process drama in teaching and learning. It involved 3-day workshop to equip teachers participating in the research project with the essential skills and the confidence to use process drama in their teaching and subsequent practice in their various classrooms.

\section{Process Drama - Drama Pedagogy}

Process drama can be described simply as the use of dramatic procedures and activities to teach subjects across the school curriculum. The main aim is to make learning more effective, challenging and yet enjoyable for the learner. It 'proceeds without a script, its outcome is unpredictable, it lacks a separate audience, and the experience is impossible to replicate exactly' (O'Neil 1995, xiii). Similar to child-centred drama introduced by Slade (1958) and Way (1969), process drama does not have performance intentions, it 'combines elements from exercises, dramatic play and theatre, creating a new form' (Tor-Helge 2008, 321). Process drama includes practices labelled: drama improvisation, teacher-in-role, drama across the curriculum and mantle of the expert.

The practice of process drama is said to have originated with the work of Harriet Finlay-Johnson who worked as a teacher in the early 1900s. O'Toole attests that 'within the community of drama teachers and workers, this cyclone (Finlay-Johnson) blew drama for learning right back to the centre of attention, not just in the UK' (O'Toole $2009,101)$. Finlay-Johnson's approach was to aid children unlearn the conventional relationship between teacher and pupil 'by substituting those of fellow workers, friends and playmates' (Finlay-Johnson 1912, 9). FinlayJohnson predominantly used drama improvisation which involves creating drama without an already existing script. The process is comparable to children's spontaneous play which often emanates from instinct and desire (Baldwin 2012, 137). However, using this approach in teaching requires teacher guidance aimed at achieving the lesson's objectives. Drama improvisation is very beneficial when used as a teaching method, as it 'develops pupils' confidence, encouraging them to be creative, to cooperate, negotiate, speak and listen' (Farmer 2012, 95). Although all children do not have the same levels of creative abilities, it has been argued that every child has innate creative abilities which aids them to participate in varied forms of play (Way 1969; Craft 1997; Baldwin 2012). These creative abilities are displayed when children are given the opportunity to explore learning through creative activities which include drama improvisation.

In line with the practice of Finlay-Johnson, Heathcote's acclaimed drama practice emphasized drama as a learning tool and her approaches became popular in Britain from the 1970s. O'Toole confirms that 'teacher-inrole... is considered one of Heathcote's most famous "inventions' (O'Toole 2009, 103). In this approach, the 
teacher takes a role, the pupils are given various roles, and learning is achieved through the fictional world they create together. Bolton describes drama orientated around a teacher-in-role approach as 'a partnership between teacher and children as agents, a 'folding in' of teacher's intentions with the children's intention' (Bolton 1980, 71).

Another teaching and learning approach promulgated by Heathcote is the mantle of the expert. Nelson (2011, 81) describes mantle of the expert as a learning process in which 'students in role as experts, stakeholders or problem-solvers are confronted with a real or fictitious problem and are asked to question, debate, discuss, consider and come to a resolution for that problem'. The teacher takes the role of an imagined client and makes progressive demands on the learners, who take on roles as professionals who are destined to 'trouble-shoot' various challenges in the imagined enterprise. Mantle of the expert operates within its own conventions, thus, although the learners are enrolled as experts:

... they must never (within the fiction) be asked to create the actual objects. If they had to do this their inexpertness would become immediately apparent. They, in actuality will design, demonstrate, explain, draw to scale, or cut out templates exactly as such firms would (Heathcote and Bolton 1995:18).

The prescribed outcomes to be submitted by pupils, as suggested by Heathcote give children an added opportunity to develop their creativity in inventiveness and co-ordination. In Matusiak-Varley's observation of this approach, 'pupils participate in teams, learn from, and teach one another, exercise leadership by taking initiative in problem solving, and communicate their ideas to justify their courses of action' $(2011$, 36). As Marzano notes, 'tasks that involve problem solving, decision making, systems analysis, creating metaphors, creating analogies, and the like are complex in nature. Being involved in such tasks certainly enhances students' understanding of content' $(2003,119)$. Heathcote's mode of practice has been appraised as child-centred; 'empowering children, respectfully offering them significant, imagined responsibilities and authentic problems to solve' (Baldwin 2012, 2). In this way, pupils are active participants and not the passive recipients of the teacher's knowledge. This approach is consistent with constructivists' recommended procedures of effective teaching and learning, where children are given the opportunity to explore and discover knowledge with the teacher's lead (Woolfolk 2013, 256). The foregoing appraisal has positioned process drama as an effective child-centered approach, for teaching and learning.

\subsection{Drama's Impact on Teaching and Learning}

Several researchers have used drama pedagogy and attest to its efficacy. For instance, Taşkın-Can (2013) used dramatic activities in the teaching of the topic 'light and sound' in a science unit in Turkey and confirms the effectiveness of drama pedagogy. The researcher used drama pedagogy in the experimental group whilst the control group were taught through traditional methods. Taşkın-Can reports that at the end of the session there was a:

... statistically significant difference between the achievement and scientific process skills test of students - of the experimental group where the creative drama education had been applied and the control group taught through teacher-centred instruction - in favour of the experimental group' $(2013,126)$.

The use of dramatic processes is even more apposite in the teaching of a second language. In research conducted at the Simin Language Institute in Iran, the researchers observed that pupils lacked opportunity to use English language outside the classroom and that using drama methods in teaching English as a foreign language provided opportunity to use English language in context which led to greater achievements in the 'learner's oral proficiency'. According to the authors, aside the success in improving learner's oracy, the drama process also 'improved the learner's confidence and motivation which ultimately lead to the development of positive selfconcepts' (Nazeryan, Jahandar, \& Khodabandehlou $(2013,223)$. In a similar project on playbuilding with Ghanaian children, it was observed that aside learning from the subject of the drama created, participants also benefited from enhanced creativity, interpersonal skills and language acquisition (Asiedu \& Brew, 2016). Benefits in engaging students in drama were also attested by Malay students who were engaged through dramatic activities to develop interest in science careers. In reporting the outcomes, the researchers indicated that aside students' enhanced interest in the sciences, the students confirmed that 'creative drama had developed their courage, social skills, teamwork, creativity, self-reflection, presentation skills, critical thinking skills, and problem-solving skills' (Ying-Chyi, Yang \& Lin, 2020). In another illustration, O'Toole and Stinson conducted a study to ascertain the impact of drama engagement and oracy with year 4 pupils in Australia. In partnership with the class teacher, the researchers engaged the pupils in creating and performing scenes using a story as a stimulant. A significant achievement was that 'the students became much more conscious of language, how it impacted on meaning and their own processes of working with language' (O'Toole \& Stinson, 2013: 172). It is notable from submissions of practitioners and researchers, that dramatic activities offer several benefits for participants. However, it has been established that success of process drama depends on teachers' attitude and understanding of the process. 


\subsection{The Role of the Teacher in the Use of Process Drama}

Drama pedagogy works best in the classroom when the teacher is able to 'shift from the most common and familiar styles of teaching and to relinquish a significant degree of lesson ownership and even content to the children' (Baldwin 2012, 27). Additionally, the ability of a teacher leading any drama process to effectively 'scaffold' the activity based on needs and challenges of learners is prominent in educational drama (O'Toole 2009; Baldwin 2012; Matusiak-Varley, 2011). Furthermore, the teacher should be able to help the learners 'discover and appreciate the satisfaction to be gained' from their involvement (Somers 1994, 45). In Winston's approach, the teacher should:

... imagine the lesson as an excursion through a wood, where the teacher's duty is to know the terrain well and make sure that everyone stays together, goes in the same directions and gets to the planned destination more or less at the same time. However, because this excursion is across interesting terrain, there are many points along the way where we will stop to explore. Here children will be told what they might look for and where they are allowed to explore before coming back into the group $(2004,11)$.

Winston's suggestions place more emphasis on the fact that although process drama involves child's play, the teacher should remain focused and lead the pupils to achieve the specific learning objectives in addition to other benefits the drama provides. Furthermore, teachers facilitating drama with students "need to have a capacity for rapid decision-making, group management skills, a tolerance of incompleteness and the ability to create a positive learning atmosphere' (Lehtonen et al., 2016). In Ghana, it appears most teachers are not familiar with drama techniques and obviously need training that will equip them with roles they ought to play in using process drama. For this purpose, I facilitated a 3-day workshop to equip teachers participating in the research project with the essential skills and the confidence to use process drama in their teaching.

\section{Methodology}

This research was conducted through practice. It 'engages specific aspects of theatre and performance as innovative process' (Kershaw et al 2009: 64). Research through practice often follows qualitative research approach that allows the researcher to collect data with special consideration for the research context and activities that involve participants. As Creswell has observed, in qualitative research, 'the final written report or presentation includes the voices of participants, the reflexivity of the researcher, a complex description and interpretation of the problem and its contribution to the literature or a call for change' (Creswell 2013: 44). This approach was apt for this research project because it was experimentation of process drama with participants, and data was collected through observation, and the report included verbatim contributions of participants.

The experiment was carried out with twelve primary school class teachers in Ghana. The teachers who joined this project did so on voluntary basis since it was not part of their mainstream work. The project was planned in two phases; a 3-day workshop to train participating teachers and the practice by teachers in their individual classrooms. In the Ghana education system, teachers in lower classes teach all subjects in the same class, whilst others in upper primary classes teach at least two subjects in two or three classes. Science biased teachers teach mathematics and science whilst humanities biased teachers teach English language, citizenship education, religious and moral studies, and creative arts. During the workshop the teachers were grouped based on the subjects they teach. Within the three days, the teachers were taken through various drama procedures that could enhance teaching and learning. The activities were particularly drama improvisation and mantle of the expert.

\section{Practice of Drama Improvisation During the Workshop}

To practise improvisation with the participants, I selected a combination of two topics from the Ghana Education Service (GES) mathematics syllabus for primary schools, Measurement of Money, and Direct Proportion by Unitary Method. The objective of the lessons was for the pupils to be able to recognize the value of various denominations of the Ghanaian cedi and use them in appropriate exchanges. The improvisation explored a market scene. In this case I functioned as a teacher/facilitator whilst the teachers/participants became the pupils.

The market created during the drama improvisation was an imitation of the open market system in Ghana. In role as a housewife, I told the pupils that my mother-in-law was paying a visit and I needed to prepare some food for her. I then told them that I needed help with the shopping. They were happy to help and so we quickly set up the market. Some pupils in the role of market women sold the various items needed for the meal, whilst others did the buying. Because we did not have the actual items, I asked the pupils playing market traders to write the names of their wares on A4 size manila cards so buyers could identify their goods. I then gave the buyers improvised money (these were old greeting cards cut out in varied shapes with various amounts written on them). Sellers and buyers engaged in bargaining, a customary way of doing business in Ghanaian markets. After each operation, we assessed the exchange to verify the correctness of the transaction. This included:

$>$ the unit cost of the item,

$>$ the quantity bought by customers,

$>$ the total cost of items purchased, 
the amount of money given by customers,

what was given back as change.

In this exercise, the improvisation offered opportunity for pupils to use various denominations and to identify their values. The activity also integrated various forms of calculations: addition, subtraction, multiplication, and division. As with the nature of process drama, the pupils learn other skills during the process; both buyers and sellers experienced bargaining and negotiations. The sellers wrote the names of items they were selling, and this helped in spelling and writing. The use of used old greeting cards was to show participants that they did not need real items for improvisation. Drama is make-believe and if all players agree on what a particular item represents, it can be used as such.

The participants (math and science teachers), now working on their own, improvised a scene that depicted a typical Ghanaian scenario in a compound house in Ghana. In the drama, a teacher took the role of a landlord distributing the cost of a water bill to the rest of the group in role as tenants. He first mentioned the total amount as three hundred and fifty Ghana cedis ( $\mathrm{GH} \not 350.00)$ and the total units of water used as 28 . The first task was for the tenants to calculate the cost of each unit. This came to twelve Ghana cedis, fifty pesewas (GH $\varnothing 12.50)$ per unit. The number of persons in each family was then counted to calculate the number of points. For instance, if you are a couple living with three children you have five points. Each tenant then multiplied their points by the unit cost. In this case, a tenant who has seven people in the family pays eighty-seven Ghana cedis, fifty pesewas $(\mathrm{GH} \notin 87.50)$. Each tenant calculated and paid various sums that sometimes required the landlord to give them change.

An interesting part of what the teacher/landlord did was to always do the calculation of each person and provide a wrong answer. The tenant then protests and provides the correct answer to which the other tenants had to agree. These transactions involved the use of money and integrated four arithmetic operations. The observing group applauded this group for the innovative way they handled the lesson. However, they felt that integrating all the equations in a lesson might be difficult for pupils at a certain level. In response, the science and mathematics teachers explained that in the selected topic all the equations are used because that lesson is taught after the teacher has done lessons on the four arithmetic operations. Participants felt that the landlord's comic actions made the lesson lively and pupils could contribute happily whilst not recognizing the activity as a mathematics lesson. It was observed that drama improvisation created an environment which alleviated the fear of mathematics, as it linked real-life instinctive mathematics to the taught classroom mathematics and replaced the tense classroom environment with a flexible and relaxing one.

\subsection{Practice of the Mantle of the Expert approach During the Workshop}

After a successful exercise with drama improvisation, the participants were somehow equipped to try a more complicated approach, mantle of the expert. For the practice of this, I selected two topics from the GES syllabus: Natural Disasters and Individual, Education and Work from the science and citizenship education syllabus respectively. The background to this assignment was that several cities and towns are not well planned. Some houses are built on waterways, which are flooded when there is persistent rain. In some vicinities, there are no access roads for fire officers to get to fire spots. Some towns lack proper health facilities and schools. Using the mantle of the expert strategy, we assumed that the participants had gone through some level of education and had the expertise to do a better design of a city. The participants worked in two groups performing the same task with various levels of expertise: city engineers, architects, builders, town planners, for example. Their duty was to design a model city with all important amenities and components sited at appropriate places. As per the convention of mantle of the expert every activity by the pupils was representational (Heathcote and Bolton, 1995). Each group was given materials, including manila cards, stickers, felt pens, ruler, and pencils. The groups had to identify their individual roles and contribute to the plan. They were expected to do a presentation on their proposed design to the other group, who would be in role as delegates from the Bank of Ghana, donor agencies, ministries, and opinion leaders. They would then make comments and ask questions. This was to provide opportunity to discuss the design and for the teacher to fill in gaps where necessary. It also gave opportunity for the pupils to earn critical thinking and critiquing skills in addition to the subject objective of taking care of the environment.

After the presentation of the first group, the observing group suggested they could place the zoo near the forest reserve instead of placing them far apart. They also observed that positioning the industrial area near the parliament house was inappropriate for security reasons. Additionally, the pollution of noise, chemicals and smoke could affect people who worked around the ministries. The observations were legitimate concerns that gave the learners the chance to learn new concepts.

Before the presentation of the second group, the leader introduced the experts as city engineer, chief architect, contractor consultant, queen mother of the town and district chief executive. In Ghana most lands belong to traditional leaders, thus before any project could be initiated, these custodians ought to be consulted and co-opted as beneficiaries. The addition of the queen mother to their list for presentation was a great initiative. After their presentation, the observing group commended them for a good road network but realized they had not earmarked any space for the processing of liquid and solid waste. It was also pointed out that although the city was very big, 
they had proposed only one hospital and positioned the residential area close to the industrial area, which might expose residents to pollution-related diseases. They also indicated the market was too far away from the residents and so proposed satellite markets at vantage points. This activity was the most participatory and engaging, and participants did not want to stop. At the end of the workshop the teachers felt they were well equipped and prepared to use drama in their teaching.

\section{The Classroom Follow-Up Experiments}

The experiment with teachers had equipped them to use various drama processes in their lessons. The teachers went on to use procedures they have learnt in their classrooms which I observed. Kwabena, Abena and Akwasi (pseudonyms) used drama improvisations in their English reading, citizenship education and science lessons respectively. Yaa (pseudonym) managed to use mantle of the expert approach in teaching an English language lesson. The following discusses how these teachers practised process drama in their teaching during the project period.

In his English reading lesson for basic 2, instead of just reading the story titled Bedtime, which has been his approach over the years, Kwabena decided to help the pupils use the script as a stimulus for improvisation. The story was already written in dialogue. There were only six lines for three characters in this script - mother, son and daughter. The original dialogue was as follows:

Andrew: Mummy, please look at Awo, she has been yawning. I can see from her eyes that she is feeling sleepy. So, she is dozing.

Mummy: Please tell her to go to bed.

Andrew: Awo, you are feeling sleepy; mummy said you must go to bed.

Andrew: Please mummy, listen to Awo, she is fast asleep, and she is snoring.

Mummy: She has slept for a long time, wake her up. (Andrew wakes her up)

Awo: I was dreaming when you woke me up. You have disappointed me. Ah! It was a pleasant dream.

The pupils had no prior knowledge of this script. The teacher created space in front of the class, placed a mattress in the corner and assigned the roles to three pupils. As they went through the script the pupils were not content with those restricted lines. Obviously, it was just boring, so they started adding other characters, more lines and actions. They kept reviewing the play until the lesson ended.

I prompted the teacher to limit his intervention to class control and correction of sentences and leave the creative aspect to the pupils. To the amazement of the teacher, the pupils showed their creative abilities by modifying the script. There were only a few conflict situations that usually characterize child's play. It was often to do with who plays what and what to add to the story. These were usually resolved quickly by the pupils but on one occasion the teacher had to intervene. The children were able to modify the script as they learnt new words and expressions accompanied with actions. This teacher had always underestimated his pupils, but the drama changed his perspective. He shared these thoughts with the other participants in a feedback session:

I realized that the children have a lot of hidden talents and if they are given the opportunity they can excel. In the performance of Bedtime, I was surprised at how much these children observe what goes on at home and around them. Initially, I was doing it my usual way- dictating what they should do, but madam (referring to researcher) prompted me to leave them alone and observe them. Surprisingly, the children did three different performances on the same theme. They just adopted roles and performed them. A mother came from the market and was so tired and still had to cook for the children, one person played the security at the gate, another had just woken up from bed and was stretching, children washed plates after eating, another was sweeping the room. It was just like how they play on their own outside; and everybody wanted to play a part; it was very interesting. I have really learnt a lot. This project has really equipped me with valuable skills, and I am going to continue using them in my teaching (Kwabena, class teacher/participant).

Following the success of this initial lesson, the teacher tried another lesson about the weather, in which the pupils were supposed to learn an already published script and perform. This was a complete failure because the subject was too abstract, and the children could not contribute to it. People hardly talk about the weather in Ghana and most of the words were not familiar to these Basic 2 pupils. What I deduce from this is that these children were not ready for drama that uses an already written strict script that has no room for innovations. Rawlins and Rich make the point that 'Students need the confidence that comes from having practised basic skills before they can become involved in more advanced Drama sessions' $(1992, \mathrm{v})$. Introducing children to a form of drama that is above their level might result in these children losing interest in drama at this early age. I also deduced that pupils are able to engage in creative activity when the subject is familiar in their environment as observed in the first lesson.

I also observed Abena's citizenship education lesson on the roles of members of the extended family. A lot of children in Ghana live with their own parents and the extended family members in family houses. The lesson was to equip the pupils with different roles various members of the family are expected to play. Abena decided to 
use dramatization for this lesson. Some of the pupils used costumes but they did not have to change completely, they wore them over their school uniforms. The grandfather, who is supposed to be the head of the extended family, called all the members of the family to a meeting. The grandfather then asked each of them to say what their roles in the family were. As each mentioned their roles, conflicts arose when the grandfather or another member of the family challenged a role a family member purported to perform. For instance, the mother challenged the father who said he paid their children's school fees. The mother insisted she had been paying the fees. The grandfather, performing his role as the one who settles family disputes, resolved the issue and advised the embarrassed father to face up to his responsibilities. The teacher stopped the action and asked questions about the roles and emphasized issues where necessary. At the end, whilst the cast were still out front, the teacher did a narration and sometimes asked some of the cast to replay their roles to emphasize the main points in the lesson. The pupils had to improvise in this drama, which gave them the opportunity to express themselves. Additionally, wearing costumes over their school uniforms and right in front of the class, made the performance suitably casual and pupils were very relaxed and confident.

Another lesson I observed was facilitated by Akwasi, who used drama improvisation to teach his integrated science lesson on Waterborne Diseases. The objective of this lesson was for the students to know the names of waterborne disease prevalent in the local communities, as well as the causes and preventive practices. The performance is transcribed as follows:

Scene 1 - A food vendor sells within a dirty environment near the school. The already-cooked food she is selling is not covered. A group of pupils in role as houseflies go searching for food. Spotting the uncovered food, they settle on it. Observing the dirty environment, the first customer refuses to buy the food. Unfortunately, some school children do buy this food.

Scene 2 - At home the pupils who had bought the food and eaten had serious diarrhoea and vomiting. Soon, they became weak, and the parents had to send them to the hospital.

Scene 3 - A mother in another family asked her children to fetch water from the stream. Before they got there, some other children had defecated in the stream whilst other children dumped refuse in it. The children drank some of the water and soon after, they started feeling unwell.

Scene 4 - At the hospital, both families brought their children to see the doctor. After the children of the first family had told the doctor about their symptoms, he diagnosed one with typhoid fever and the other with cholera. One of the children of the second family, who could not walk properly because her limbs had become weak, was diagnosed with poliomyelitis.

In this drama, the teacher, in role as narrator, filled in the gaps between the scenes. Sometimes he stopped the action to ask questions and emphasize important points. After the lesson, the teacher laid more emphasis on the causes of the diseases. He asked each of the performers to describe their actions and their possible outcomes. The pupils showed they had clearly understood this topic by answering the teacher's questions correctly. It was essential for pupils to achieve a good understanding of this topic because it linked with the community's reality. There had been an outbreak of cholera and typhoid fever in some parts of the communities where the pupils lived. Dramatization that allows pupils to encounter the problems associated with these diseases would help pupils and their families avoid practices that could transmit them. The effectiveness of this activity proves that drama could be used to enhance the teaching of science to aid a better understanding, as also shown in the experiments reported in Abrahams \& Braund (2012).

One more lesson I observed was Yaa's English listening and speaking lesson which focused on the role of various government ministries - Education, Health, Energy and Agriculture. She decided to try the mantle of the expert strategy. The teacher formed four groups to represent these ministries. She then gave each group strips cut from card on which some of the duties of the ministries were written. The task was for group members to equip themselves with the workings of the various ministries and to present two representatives to be interviewed for the positions of ministers and deputies for those ministries. The groups settled to the task of exploring the tasks the teacher had given them and brainstorming to add more points. When the time allowed for this work ended, the teacher, in role as the President of the country, interviewed the representatives and wrote appointment letters for deserving representatives. Unlike some other lessons I observed, the grouping was done so efficiently that it created no noise. The teacher just numbered them 1 to 4 and so all pupils with the same numbers just moved into their groups. Although there were many pupils, the teacher was well organized and very much in control. All the pupils were working and interacting concurrently in special ways. In role as the President, the teacher had the opportunity to comment on the contributions and fill in all gaps. She also made it clear to the pupils when she was herself as the teacher and when in role as the President. The tasks were challenging but enjoyable for the teacher and the pupils.

\section{Challenges of the Classroom Process Drama Practice}

Although the teachers were able to use drama approaches to achieve their lesson objectives and accrued other benefits for the pupils, the sessions were not without challenges. The major ones were the large class numbers and 
limited space in the classrooms for more interactive classroom drama. Because of this limitation some pupils could not participate effectively as the teachers had to manage with what was available. Drama is fun and children love to play in various forms; some children played to the gallery whilst others made attempts to play to perfection. This is obviously not the path process drama takes, especially when it is focused at achieving specific lesson objectives. Also, there were instances some pupils were not able to play the roles assigned well and others laughed at them. In most of such instances the pupils did not feel humiliated as they joined the euphoria. There was one example, however, where a pupil felt humiliated when the role was given to another person. I advised the teacher to give the pupil another role which was well performed and applauded.

I also observed occasions where pupils tried to imitate well-known actors they see on television. This was discouraged because the pupils needed to gradually develop their own innate creativity rather than copy celebrities. Furthermore, in all the experiments, the teachers could not work within their official timetable stipulated time as it always run into the time for the next lesson. This challenge was not peculiar to these teachers as Hornbrook (1989) had observed this in some UK teachers who used Heathcote's approach. Also, in Wessels's use of drama to address racism with students in Mississauga, she indicated that insufficient time deprived them of valuable portions of the performance and discussions (Gallagher, Ntelioglou, and Wessels, 2013). Another challenge for the teachers was class control. Akwasi's class for instance had sixty-two pupils and control was very difficult, especially as he had to put aside the cane, his main tool for discipline over the years. Some climbed their desks to be able to see the action taking place in front of the class, making a lot of noise which sometimes made it difficult for the rest of the class to hear the players. Teachers in other classrooms also complained about the noise that was obviously distracting the attention of pupils in their class. Teacher Akwasi at point was tempted to go for his cane. The need for teachers to have team management skills prescribed by Lehtonen et al. (2016) became evident. Teacher Akwasi eventually invited another teacher who was free to help with class control.

\section{Conclusion}

The purpose of this research project was to introduce non-drama teachers to the use of drama pedagogy to enhance teaching and learning. These teachers, before the project, were not accustomed to play-based approaches to teaching and it was the first time they were using process drama amidst dearth of conducive infrastructure for effective drama activities. Notwithstanding these hitches, the teachers managed to use process drama, a childcentered approach, to liven up their classrooms and achieve their teaching objectives. Furthermore, the pupils gained other intrapersonal and interpersonal benefits from the drama processes which contributes to the findings of other researchers. However, considering the difficulties these teachers had to go through in using full process drama in their teaching, a more simplified and a limited use of appropriate drama strategies and games might be more feasible in the current classroom context. It is therefore recommended that teachers are introduced to techniques that might require minimal training but can aid them gain confidence, skill, and motivation they need to effectively practice play-based learning. Such strategies should be designed in consideration of the limited time and space available for lessons as well as large class numbers in the current classroom context. The expectation is that the recommended approach might make it easier for teachers to make teaching and learning more fun and enhance pupil's achievements.

\section{References}

Abrahams, I. \& Braund, M. (eds) (2012). Performing Science: Teaching Chemistry, Physics and Biology through Drama. London: Continuum International Publishing Group.

Asiedu, A. \& Brew, F. (2016). Experimenting Playbuilding with Ghanaian Children. Drama Research: International Journal of Drama in Education, 7 (1), 1-17. http://www.nationaldrama.org.uk/wpcontent/uploads/sites/2/DR7-Article-3.pdf.

Baldwin, P. (2012). With Drama in Mind: Learning in Imagined Worlds. London: Continuum International Publishing Group.

Bolton, G. (1980). Drama in Education and TIE: a Comparison. In Learning Through Drama: Essays and Casebooks on Theatre in Education, Tony Jackson (ed) 69-77. Manchester: Manchester University Press.

Creswell, J. (2013) Qualitative Inquiry \& Research Design Choosing Among Five Approaches, 2nd edition, Los Angeles : SAGE Publications.

Craft, A. (1997). Can you Teach Creativity? Nottingham: Education Now Publishing Co-operative.

Farmer, D. (2012). 101 More Drama Games. Self-Published at Lulu.com.

Finlay-Johnson, H. (1912). The Dramatic Method of Teaching. Boston: Ginn \& Company.

Gallagher, K., Burcu Yaman N. \& Wessels, A. (2013). Listening to the Affective Life of Injustice: Drama Pedagogy, Race, Identity, and Learning. Youth Theatre Journal, 27 (1), 7-19. https://doi.org/10.1080/08929092.2013.779349.

Heathcote, D. \& Gavin, B. (1995). Drama for Learning: Dorothy Heathcote's Mantle of the Expert Approach to Education. Portsmouth: Heinemann. 
Hornbrook, D. (1989). Education and Dramatic Art. Oxford: Basil Blackwell.

Lehtonen, A., Miia, K., Mirja, K. \& Tapio, T. (2016). Promoting Creativity in Teaching Drama. Procedia - Social and Behavioural Sciences, 217 (5), 558-566.

Kershaw, B. (2009) Practice-as-Research: An Introduction, in Allegue L. et al (eds.) Practice-as-Research in Performance and Screen. Hampshire: Palgrave Macmillan, pp. 1-16.

Marzano, R. (2003). What Works in Schools: Translating Research into Action. Alexandria: Association for Supervision and Curriculum Development.

Matusiak-Varley, B. (2011). Developing Pupils' Learning through the use of Mantle of the Expert. In Key Concepts in Theatre/Drama Education, Shifra Schonmann (ed), 35-38. Rotterdam: Sense Publishers.

Nazeryan, S. Z., Shahrokh, J. \& Morteza, K. (2013). A Study of the Effectiveness of Dramatization in Teaching English on Iranian EFL Learner's Oral Proficiency. Indian Journal of Fundamental and Applied Sciences, 3 (3), 214-224. http://www.cibtech.org/jls.htm

Nelson, B. (2011). Power and Community in Drama. In Key Concepts in Theatre/Drama Education, Shifra Schonmann (ed), 79-85. Rotterdam: Sense Publishers.

O'Neill, C. (1995). Drama Worlds: a Framework for Process Drama. Portsmouth, NH: Heinemann.

O'Toole, J. \& Madonna, S. (2013). Drama, Speaking and Listening: the Treasure of Oracy. In How Drama Activates Learning: Contemporary Research and Practice, Michael Anderson \& Julie Dunn (eds), 159-177. London: Bloomsbury Academic.

O'Toole, J. (2009). Drama as Pedagogy. In Drama and Curriculum: A Giant at the Door, John O'Toole, Madonna Stinson, \& Tina Moore (eds), 97-116. Singapore: Springer.

Rawlins, G. \& Rich, J. (1992). Look, Listen and Trust. Surrey: Thomas Nelson and Sons Ltd.

Slade, P. (1958). An Introduction to Child Drama. London: University of London Press.

Somers, J. (1994). Drama in the Curriculum. London: Cassell Educational Ltd.

Taşkın-Can, B. (2013). The Effects of Using Creative Drama in Science Education on Students' Achievements and Scientific Process Skills. Elementary Education, 12 (1). DOI:10.17051/IO.77955.

Tor-Helge, A. (2008). A Comparative Analysis of the Relationship between Dramaturgy and Epistemology in the Praxis of Gavin Bolton and Dorothy Heathcote. Research in Drama Education: The Journal of Applied Theatre and Performance, 13 (3), 321-335. DOI: 10.1080/13569780802410681.

Way, B. (1969). Development through Drama. London: Longmans Green and Co.

Winston, J. (2004). Drama and English at the Heart of the Curriculum: Primary and Middle Years. London: David Fulton Publishers.

Woolfolk, A. (2013). Educational Psychology. (12th ed.). Boston: Pearson Education Inc.

Ying-Chyi, K. Chou Ding-Yah, Y. \& Chi-Chau, L. (2020). Creative Drama in Science Education: The Effects on Situational Interest, Career Interest, and Science-Related Attitudes of Science Majors and Non-Science Majors. EURASIA Journal of Mathematics, Science and Technology Education, 16 (4), 1-18. https://doi.org/10.29333/ejmste/115296.

\section{Author}

Faustina Brew is a senior lecturer, teaching Playwriting and Drama in Education at the Department of Theatre Arts of the University of Education, Winneba, Ghana. She obtained her PhD in Performance Practice (Drama) at the University of Exeter, UK in 2016. Prior to this, she had obtained an MFA degree from the University of Ghana, Legon in 2006, majoring in Playwriting. Her publications include journal articles that focus on impact of theatre on audiences, playbuilding with children, drama pedagogy, as well as stage plays - The Hot Chair, Murder of the Surgical Bone, The Prisoner and The Birth of the Mystery Child. Her interest includes: playbuilding with children, interplay between child's play and learning, impact of theatre experiences on audiences and creating thoughtprovoking stage plays. 